\title{
根域に対する灌水域の割合がカンキツ樹の乾燥ストレスに及ぼす影響
}

\author{
吉田純也 ${ }^{1 a}$ ・岩崎光徳 ${ }^{2 *}$ \\ 1 香川県農業試験場府中果樹研究所 762-0024 香川県坂出市府中町 6117-1 \\ 2 独立行政法人農業・食品産業技術総合研究機構＼cjkstart果樹研究所カンキツ研究口之津拠点 859-2501 長崎県南島原市口之津町乙 954
}

\section{Influence of the Ratio of the Irrigation Zone to Root Zone on Drought Stress of Citrus Trees}

\author{
Junya Yoshida $^{\text {1a }}$ and Mitsunori Iwasaki ${ }^{2 *}$ \\ ${ }^{1}$ Fuchu Fruit Research Institute of Kagawa Agricultural Experiment Station, Sakaide, Kagawa 762-0024 \\ ${ }^{2}$ Kuchinotsu Citrus Research Station, National Institute of Fruit Tree Science, Minamishimabara, Nagasaki 859-2501
}

\begin{abstract}
In order to determine the drip irrigation zone adequate to control drought stress, we investigated the influence of drought stress under different ratios of the irrigation zone on citrus trees. The results showed that there was a clear correlation between the irrigation zone and drought stress of trees. It was indicated that, in the case of young trees, a greater than $50 \%$ irrigation zone out of the root zone was required in order to protect them from overdryness. In the case of adult trees, over 19.5\% was necessary for 13-year-old 'Shiranui', and over 14.2\% for 21-year-old 'Haraguchi-wase'. Drip tubes should be placed within $100 \mathrm{~cm}$ from trunks where fine roots are densely distributed. An appropriate irrigation time was estimated to be 20 minutes in granite soil, 20-60 minutes in basalt soil, and 60 minutes in andesite and volcanic ash soils. In addition, it was indicated that the dripper interval should be more than $20 \mathrm{~cm}$ in granite soil and more than $30 \mathrm{~cm}$ in the three other kinds of soil to reduce water wastage.
\end{abstract}

Key Words : drip irrigation, high-quality fruit, leaf water potential, soil texture

キーワード : 土性, 高品質果実, 点滴灌水, 葉内水ポテンシャル

\section{緒言}

近年, ウンシュウミカン (Citrus unshiu Marcow.) のシー トマルチ栽培に抢ける乾燥ストレスの調節を目的として, 点滴灌水チューブを利用した栽培法が普及している. 点滴 灌水チューブは，低い水圧下でも均一に灌水できることか ら, 傾斜地が多く水圧の確保が困難なカンキッ産地に颃い ても導入しやすく, 高品質果実生産につながる技術として 生産現場からの期待は大きい（草塲ら，2007).

しかし，点滴灌水チューブを用いた灌水方法には概算の 指標（森永ら，2005）があるのみで, 品質の安定化には, 樹体の乾燥ストレスに基づいた知見が必要である。また, 点滴灌水の利用は, ウンシュウミカンだけでなく, 中晚生 カンキッへ拡大していることから, 品種, 樹のサイズ拈よ び高品質化に必要な乾燥ストレスの程度に応じた導入方法 が求められている(草塲ら，2007）.

点滴灌水チューブの灌水域には制限があるため, 導入に は, 根域に対する灌水域の容積割合が樹体の乾燥ストレス

2013 年 11 月 18 日 受付. 2014 年 5 月 14 日 受理.

* Corresponding author. E-mail: iwanori@affrc.go.jp

a 現在 : 農林水産省 食料産業局 新事業創出課
に及ぼす影響を明らかにする必要がある。これまでにも土 壌の水分含量とカンキッ樹の乾燥ストレスとの関係につい て調査した報告は多いが（貝原ら，2008; 間艼谷・町田， 1980; 高木ら，1981），根域に対する灌水域の割合に着目し た報告は少ない。間苧谷ら（1976）は, 鉢植えの3 年生“杉 山温州'を用いて，一定割合の根域への灌水で樹体水分を 維持できると報告している。しかし，樹の大きさや品種に よる違いは明らかでない.

そこで, 早生ウンシュウミカンと中晚生カンキッの主要 品種である ‘不知火’ (“清見” $\times$ ‘中野 3 号” ポンカン) の幼木执よび成木を供試し，根域に対する灌水域の割合が 樹体の乾燥ストレスに及ぼす影響について調査した. また, カンキッ園に多い土㙋別の点滴灌水の浸潤域と, カンキッ 樹の根群分布域を調査することで，樹体の乾燥ストレスの コントロールに必要な点滴灌水チューブの導入方法につい

て検討した.

\section{材料および方法}

試験 1 灌水域の割合が幼木の乾燥ストレスに及ぼす影響 一辺 $80 \mathrm{~cm}$ の正方形のブロック枠 (安山岩質土㙥, 有効 土層 : $20 \mathrm{~cm}$, 底面 : 防草シート, 台 : プラスチックパレッ ト）に植栽したカラタチ台 6 年生 ‘不知火’ 拈よびカラタ 


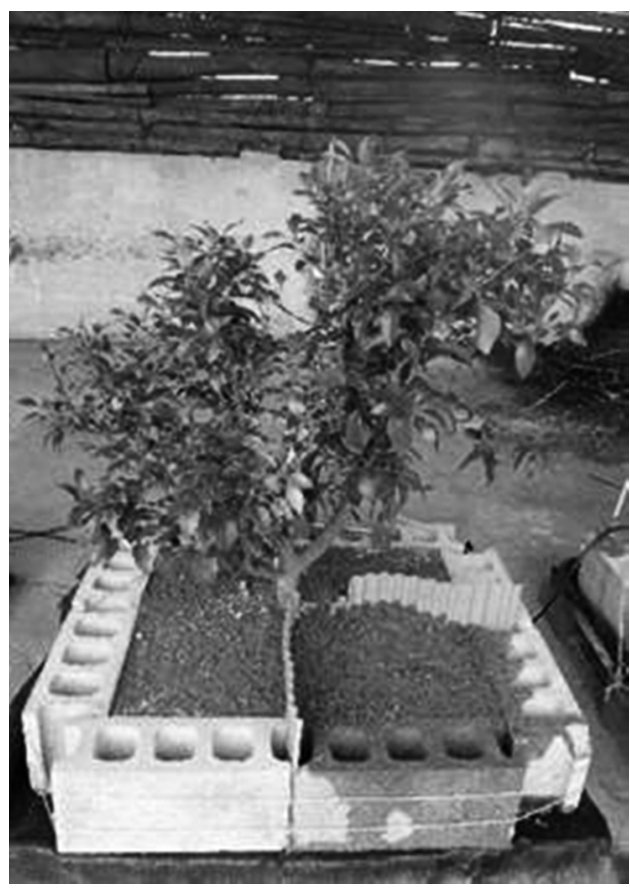

第 1 図 ‘不知火’ の 25\%灌水区の状況

チ台 5 年生 “興津早生’ ウンシュウミカンを供試した（第 1 図). 試験を開始する数か月前の植え付け時に, 灌水域 と非灌水域の根量割合が異なる 5 つの処理区を達観により 作成した。処理区は，灌水域を $100 \%$ とした 100\%灌水区， 同 75\% 灌水区，同 50\%灌水区，同 25\%灌水区，同 $0 \%$ 灌 水区とした，なお，試験終了後，全樹の根の解体調査によ り, 実際の灌水域と非灌水域の細根の割合を算出し, 当初 達観により配分した割合とほぼ同じであることを確認し た. 反復数は $100 \%$ 灌水区打よび $0 \%$ 灌水区が各区 1 樹, その他は各区 2 樹とした.

“不知火’は，樹冠拡大を想定し果実を全摘果した後， 2012 年 7 月 10 日に全処理区を全域湿潤状態にした。 その 後, 湿潤状態を維持できる 3 日に 1 回の間隔で, 7 月 30 日まで処理区別に灌水域のみ十分量の手灌水を行った。樹 体水分測定は, 岩崎ら (2012) の方法による TDR 計 (CS616, ロッド長 $300 \mathrm{~mm}$ ，（株）Campbell Scientific）を用いた枝内 水分と, Sholander ら (1966) によるプレッシャーチャンバー （Model1000，（株）PMS）を用いた葉内最大水ポテンシャ ル（以下 $\psi$ max）を測定した。枝内水分は，各樹の主幹部 を1 か所測定し，岩崎ら（2012）は，その標準誤差を枝内 体積含水率に換算して $\pm 0.30 \sim 0.46 \% \quad(\mathrm{n}=5)$ と報告し ている. $\psi \max$ の測定は夜明け前の午前 4 時頃に, 各樹 1 枚の葉を採取して行った。 $\psi$ max の測定精度は, 永田 (2003) のサンプルサイズ設計方法を用いた結果, 有意水準 $\alpha$ を 0.05 , 検出力 $1-\beta$ を 0.90 に設定した場合の 1 樹 1 葉の精度 は土0.08 MPa，2樹各 1 葉は土 $0.06 \mathrm{MPa}$ であった。 ‘興津 早生’ は，葉果比 30 程度に着果を調整した後，8月 30 日 に全処理区を全域湿潤状態にした. その後, “不知火’ 同様の処理を行いながら，9月24日まで枝内水分扎よび $\psi$ max を測定した。 な执，降雨時にはハンドリフトを用い てブロック枠を屋根下へ移動し，降雨を防いだ.

\section{試験 2-1 点滴灌水チューブの土壤別灌水域}

大型ポット（直径 $60 \mathrm{~cm}$ ）に安山岩, 玄武岩, 花崗岩, 火山灰をそれぞれ母材とする乾燥土㥽を深さ $35 \mathrm{~cm}$ となる ように詰め，各鉢の中央部に扎いて点滴灌水チューブ（ユ ニラム $\mathrm{RC}$, 点滴孔間隔 $30 \mathrm{~cm}$, 吐出量 $2.3 \mathrm{~L} / \mathrm{h}$, ネタフィ ム (株)）の点滴孔 1 孔による灌水を行った．灌水時間の 違いにより, 5 分, 10 分, 20 分, 30 分, 60 分（灌水量は それぞれ $0.19 \mathrm{~L}, 0.38 \mathrm{~L}, 0.77 \mathrm{~L}, 1.15 \mathrm{~L}, 2.30 \mathrm{~L}$ に相当) の 5 区を設け，灌水終了直後に土㙋を $5 \mathrm{~cm}$ ずつ掘り下げ ながら，深度別に灌水の浸潤半径を測定した。なお，浸潤 半径に影響すると考えられる土壌の粒径組成は，土㖶環境 分析法（土壌環境分析法編集委員会編，1997）を参考に調 査した。

\section{試験 2-2 灌水域の割合が成木の乾燥ストレスに及ぼす影響}

玄武岩質の埴壌土である果樹研究所カンキッ研究口之津 拠点䚾場に植栽されたカラタチ台 13 年生 “不知火”扣よ びカラタチ台 21 年生 ‘原口早生’ ウンシュウミカンを供 試した，両品種ともに，点滴灌水チューブ（前述に同じ） の設置本数が異なる，4 本区，3 本区，2 本区，1 本区の計 4 区を設けた。灌水チューブは植栽列に対して平行に設置 し， 1 2 本目は主幹から約 $40 \mathrm{~cm}$ (2 本目は逆側)， 3 〜 4 本目は約 $80 \mathrm{~cm}$ の位置（4 本目は逆側）に敷設した. 反 復数について, “不知火”は 1 区 3 樹, “原口早生”は 1 区 5 樹とした. ‘不知火”は2 2012 年 7 月 4 日に, “原口早生” は同年 6 月 28 日に, 全処理区の土壌を湿潤状態にした後, 透湿性シートマルチ（タイベック，ソフトタイプ，幅 $3 \mathrm{~m}$, デュポン (株)）被覆を行った。 その後は，予備試験 により灌水域を湿潤状態で維持できる $3 \sim 5$ 日に 1 回の間 隔で，30 分間（1 孔当たりの吐出量約 $1.15 \mathrm{~L}$ ）の点滴灌水 を行い, 試験 1 と同様の方法で経時的に $\psi$ max を測定した. 摘果は 7 月上旬に行い, 葉果比は ‘不知火’が 100 程度, “原 口早生’が 25 程度とした。 その他の肥培管理预よび病害 虫の防除は，両品種ともに慣行の方法に従った。試験終了 後の 10 月上旬に，“不知火’扣よび“原口早生”の試験樹 各 1 樹（4 本区を使用）の根域（本試験に打いては細根域 と同義とする）を，主幹を中心とした水平方向に半径 $60 \mathrm{~cm}, 100 \mathrm{~cm}, 150 \mathrm{~cm}, 200 \mathrm{~cm}, 250 \mathrm{~cm}$ の同心円と, 地 表より垂直方向に $0 \sim 10 \mathrm{~cm}, \quad 10 \sim 20 \mathrm{~cm}, 20 \sim 30 \mathrm{~cm}$, $30 \sim 40 \mathrm{~cm}, \quad 40 \sim 50 \mathrm{~cm}, 50 \sim 60 \mathrm{~cm}$ とに区分して掘り 取り，各区分に打ける細根重を調査した。 な抏，解体調査 に用いた試験樹のサイズは“不知火’が樹冠幅 $3.3 \mathrm{~m}$ ，樹 高 $2.7 \mathrm{~m}$, 幹周 $44.3 \mathrm{~cm}$ であり, “原口早生” が樹冠幅 $3.0 \mathrm{~m}$, 樹高 $2.0 \mathrm{~m}$, 幹周 $51.2 \mathrm{~cm}$ であった.

\section{結果}

\section{試験 1}

“不知火’括よび ‘興津早生’の 100\%灌水区の $\psi \max$ は, 
“不知火”

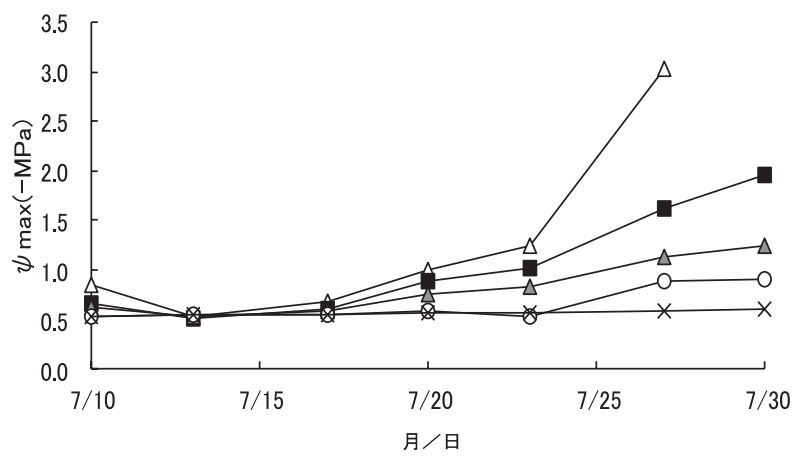

“興津早生”

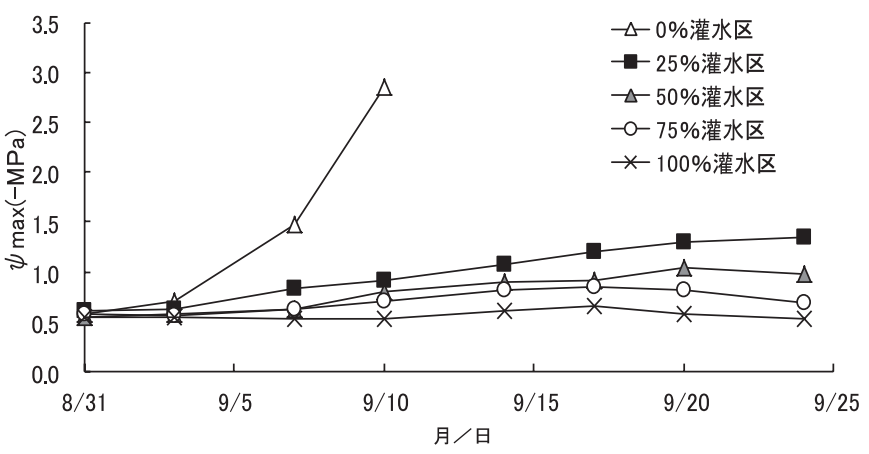

第 2 図 異なる灌水域が ‘不知火’および ‘興津早生’ 幼木の葉内最大水ポテンシャルに及ぼす影響

“不知火”

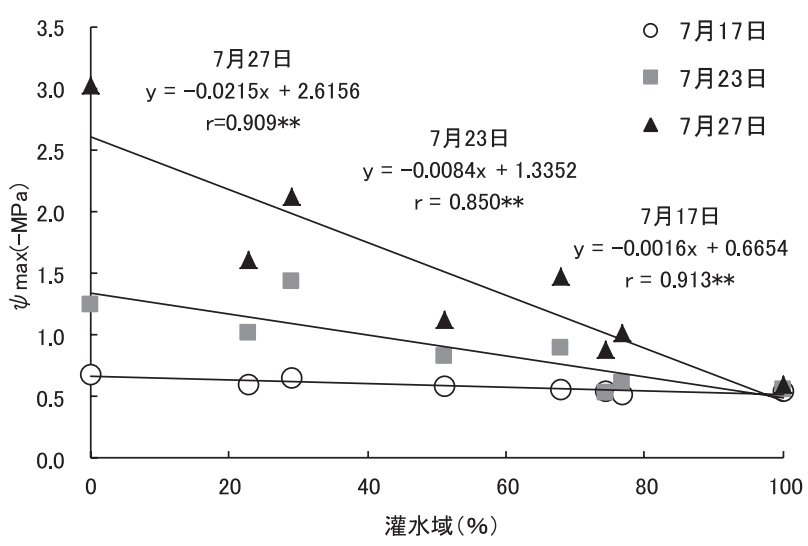

‘興津早生’

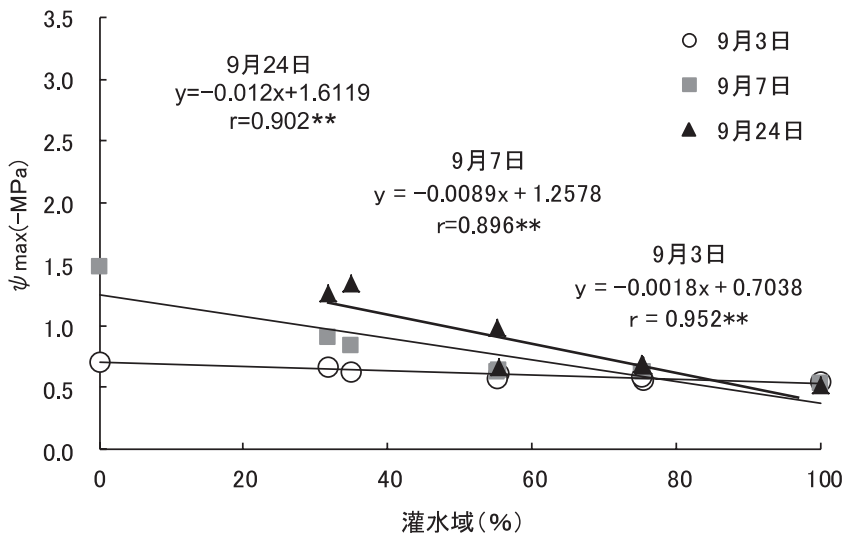

第 3 図 ‘不知火’ および ‘興津早生’ 幼木における根域に対する灌水域の容積割合と葉内最大水ポテンシャルとの相関関係 $\mathrm{r}$ は Pearsonの相関係数を示し，**は1\%水準で有意である 各灌水域は，試験終了後の解体調査により実測した細根量の比率を示す

“興津早生’の9月 24 日の 0\%灌水区は，樹体が枯死したため測定できていない

期間を通じて - 0.6 MPa程度までに, 75\%灌水区の $\psi$ max は, 期間を通じて $-0.9 \mathrm{MPa}$ 程度までに維持された（第 2 図）. $25 \sim 50 \%$ 灌水区では，期間を通じて $-1.2 \mathrm{MPa}$ 程度までに 維持されたが, “不知火’の $25 \%$ 灌水区に抏いては, 最終 的に-2.0 MPa まで低下した。 $0 \%$ 灌水区に打いては，“不 知火’で試験開始 20 日後, “興津早生’で 15 日後に $\psi$ max が $-4.0 \mathrm{MPa}$ を下回り, その後, 樹は枯死した. 根 域に対する灌水域の割合と $\psi$ max との相関分析を行った結 果，“不知火’で試験開始約 2 週間後から，“興津早生’で 試験開始約 1 週間後から試験終了時まで相関係数 0.9 程度 の高い相関関係が見られた(第3 図).

TDR 計を用いて測定した樹体の体積含水率は， $\psi$ max と 同様の推移をたどり，灌水域が大きいほど体積含水率も高 く維持されていた（第 4 図）。“不知火’に打いては 50 〜 $100 \%$ 灌水区の体積含水率の減少幅が約 $0 \sim 2 \%$ 内で維持 されたのに対し，25\%灌水区では最終的に約 4\%，0\%灌 水区では約 7\%の減少が認められた。 ‘興津早生’ に打い ては, $75 \sim 100 \%$ 灌水区の体積含水率の減少幅が約 $0 \sim 2 \%$ 内で維持され，50\%灌水区では最終的に約 4\%，25\%灌水
区では約 5\%，0\%灌水区では約 11\%の減少が認められた。

\section{試験 2-1}

1 点滴孔からの点滴灌水の土䁃別浸潤域について，水平 方向への浸潤性は，火山灰土壌と安山岩質土壃が高く, 60 分の灌水による深さ $15 \mathrm{~cm}$ までの浸潤半径の平均值は，火 山灰土壤が $15.2 \mathrm{~cm}$, 安山岩質土壤が $14.5 \mathrm{~cm}$ であり, 玄 武岩質土壤が $11.5 \mathrm{~cm}$, 花崗岩質土䁃が $8.3 \mathrm{~cm}$ であった（第 5 図). 垂直方向への浸潤性は, 花崗岩質土壌が最も高く, 10 分で深さ $30 \mathrm{~cm}$ まで, 30 分で $35 \mathrm{~cm}$ まで浸潤した。次 いで，玄武岩質土壌が 20 分で $30 \mathrm{~cm}$ まで，60 分で $35 \mathrm{~cm}$ まで浸潤した. 安山岩質土壇と火山灰土塞はほぼ同等で, いずれも 60 分の灌水で $25 \mathrm{~cm}$ であった。深さ $30 \mathrm{~cm}$ 程度 までをほぼ均一に灌水するために要する灌水時間は，花崗 岩質土壤や玄武岩質土䁃に括いて $20 \sim 30$ 分, 安山岩質土 㙵や火山灰土㙵に打いては約 60 分であった。

\section{試験 2-2}

“不知火’打よび“原口早生”のいずれの処理区に打い ても，時間の経過に伴い $\psi$ max の低下が認められ，その程 度はチューブの敷設本数が少ない㴗ど大きくなった（第 6 
“不知火”

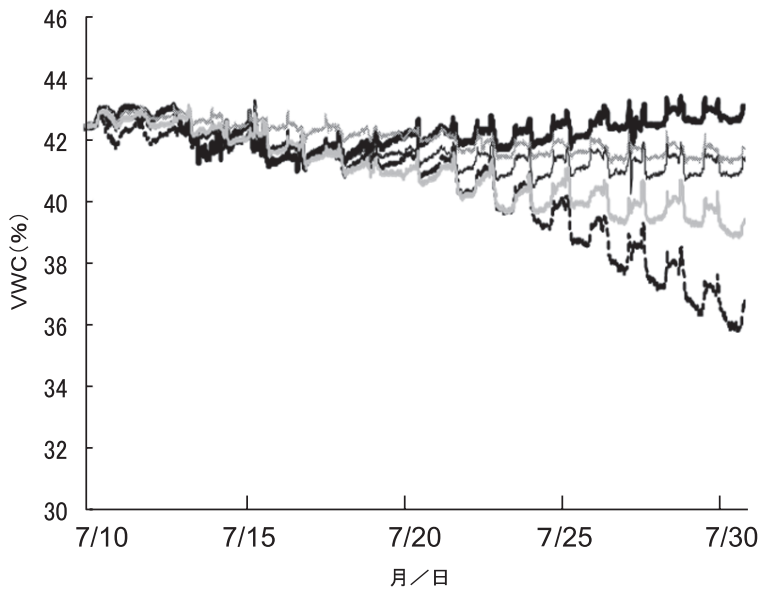

‘興津早生’

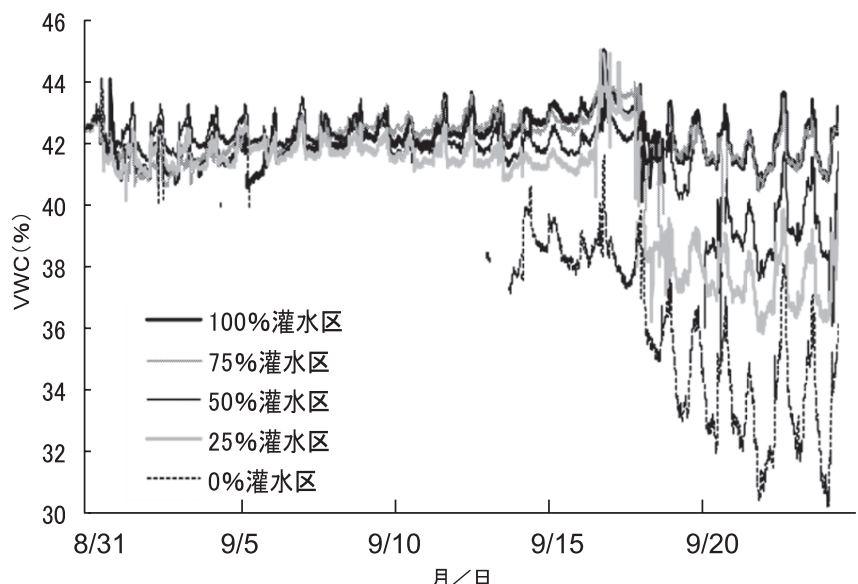

第 4 図 異なる灌水域が ‘不知火’ 抒よび“興津早生”幼木の樹体の体積含水率（VWC）に及ぼす影響 “興津早生”の $0 \%$ 灌水区の VWC 值は測定器の接触不良のため一部データ欠損
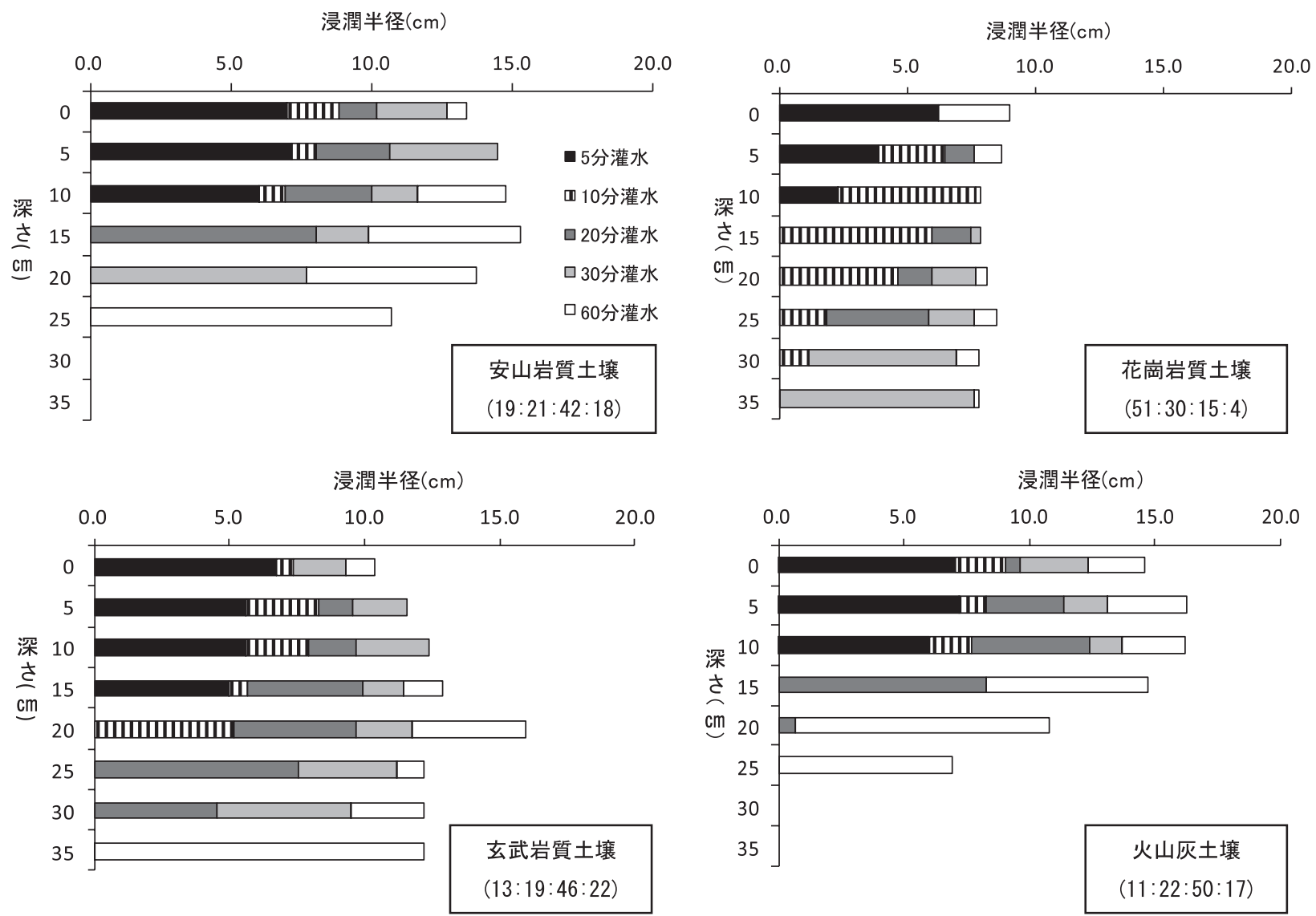

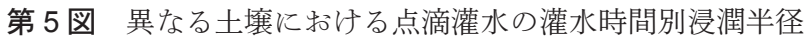

土壌母材下の括弧内は各土㙥の粒径組成を表し，荒砂：細砂：微砂：粘土の比率を示す

図)。両品種の 4 本区执よび“原口早生”の 3 本区の $\psi$ max の低下は比較的少なく, “原口早生”に打いては, 一度低下した $\psi \max$ が，期間終盤にやや回復する傾向も認 められた。 $\psi \max -1.2 \mathrm{MPa}$ 程度で樹の衰弱が見られはじめ たことから，“不知火’の 3 本区は灌水開始後約 66 日，2 本区拈よび 1 本区は約 45 日，“原口早生”の 2 本区は約
60 日，1 本区は約 53 日で測定を中止した。

根群調査の結果から，細根の垂直分布では，地表から $30 \mathrm{~cm}$ までの深さに“不知火’で全細根の 94.7\%が，“原 口早生’で $94.2 \%$ が分布していた。水平分布では，いずれ の品種に颃いても主幹から半径 $60 \sim 100 \mathrm{~cm}$ までの位置に 最も多くの細根が分布していた。 細根密度は“不知火”，“原 
“不知火”

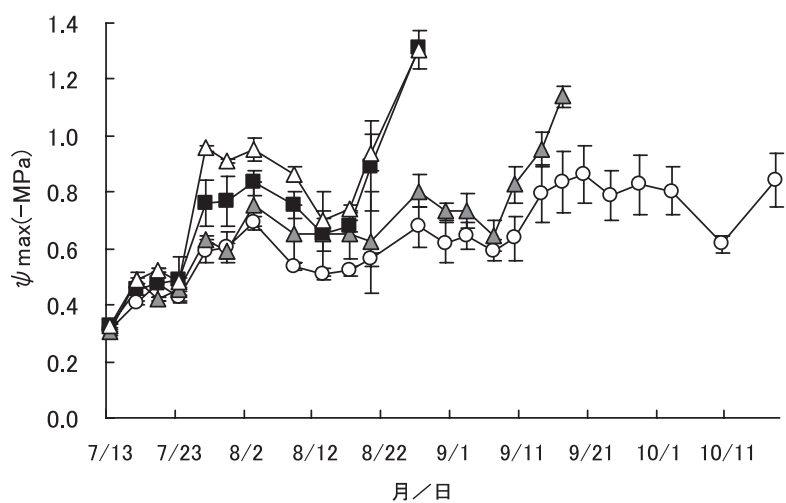

“原口早生”

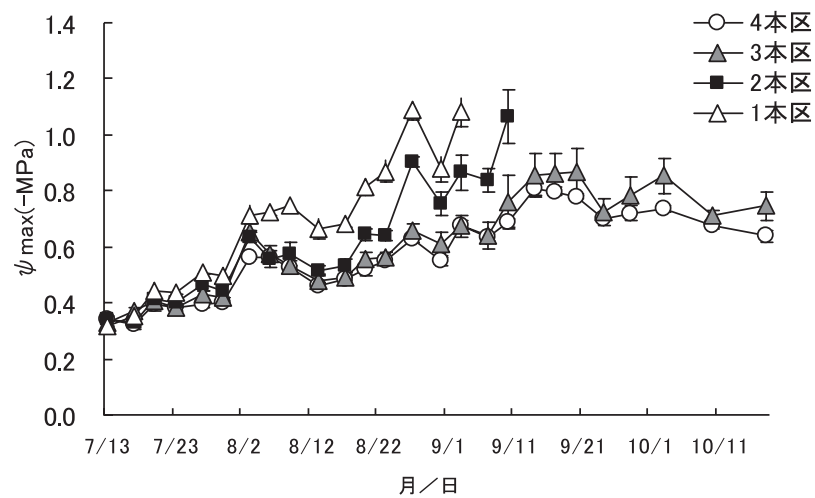

第 6 図＼cjkstart灌水チューブの設置本数が ‘不知火’抢よび ‘原口早生’成木の葉内最大水ポテンシャルに及淁す影響 図中の緃棒は標準䛊差を示す（n=3）

第 1 表 “不知火’ 成木に打忊る細根密度 $\left(\mathrm{DWg} \cdot \mathrm{m}^{-3}\right)$ 分布

\begin{tabular}{cccccc}
\hline \hline \multirow{2}{*}{ 土裹の深さ } & \multicolumn{5}{c}{ 主幹からの水平距離 } \\
\cline { 2 - 6 } & $0-60 \mathrm{~cm}$ & $60-100 \mathrm{~cm}$ & $100-150 \mathrm{~cm}$ & $150-200 \mathrm{~cm}$ & $200-250 \mathrm{~cm}$ \\
\hline $0-10 \mathrm{~cm}$ & 459.8 & 645.3 & 371.1 & 251.9 & 24.8 \\
$10-20 \mathrm{~cm}$ & 222.5 & 236.0 & 59.0 & 14.7 & 20.3 \\
$20-30 \mathrm{~cm}$ & 294.9 & 167.5 & 28.2 & \\
$30-40 \mathrm{~cm}$ & 161.2 & 104.3 & & & \\
\hline
\end{tabular}

第 2 表 ‘原口早生’ 成木に打細根密度 $\left(\mathrm{DWg} \cdot \mathrm{m}^{-3}\right)$ 分布

\begin{tabular}{cccccc}
\hline \hline \multirow{2}{*}{ 土裹の深さ } & \multicolumn{5}{c}{ 主幹からの水平距離 } \\
\cline { 2 - 6 } & $0-60 \mathrm{~cm}$ & $60-100 \mathrm{~cm}$ & $100-150 \mathrm{~cm}$ & $150-200 \mathrm{~cm}$ & $200-250 \mathrm{~cm}$ \\
\hline $0-10 \mathrm{~cm}$ & 164.5 & 420.0 & 268.1 & 144.8 & 21.8 \\
$10-20 \mathrm{~cm}$ & 247.4 & 205.5 & 186.9 & 41.1 & 14.2 \\
$20-30 \mathrm{~cm}$ & 182.8 & 180.9 & 129.1 & 12.8 \\
$30-40 \mathrm{~cm}$ & & 35.0 & 23.1 & & \\
$40-50 \mathrm{~cm}$ & & 41.7 & & & \\
$50-60 \mathrm{~cm}$ & & 33.5 & & & \\
\hline
\end{tabular}

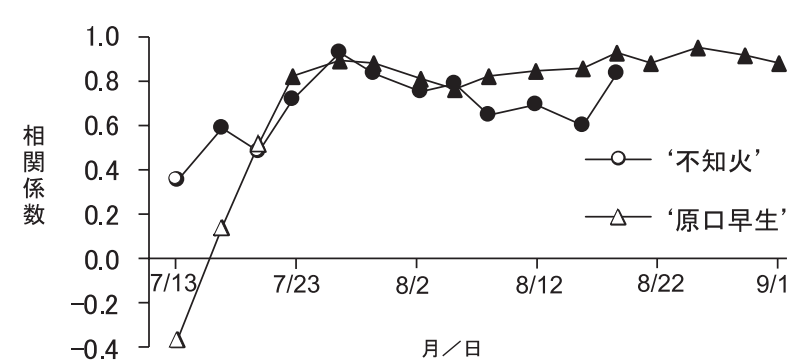

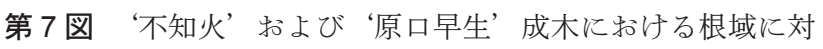
する灌水域の容積割合と葉内最大水ポテンシャルとの 相関関係

相関係数は Pearsonの相関係数を示し，黒塗りのプロッ トは 5\%水準で有意である $(\mathrm{n}=12)$

口早生’ともに，地表から $10 \mathrm{~cm}$ までの深さで，主幹から $60 \sim 100 \mathrm{~cm}$ の位置に捈いて最も高かった（第 1,2 表).

なお，根群調査の結果をもとに根域に配置される点滴孔 数を算出し, 試験 2-1 で得られた立武岩質土㙋に打ける点
滴灌水の浸潤域を用いて, 根域に対する点滴灌水の浸潤域 割合を容積比で算出すると, “不知火’の 1 本区は根域の $5.5 \%$ に相当し，2 本区は $11.0 \% ， 3$ 本区は $15.3 \% ， 4$ 本区 は $19.5 \%$ に相当した。 また，“原口早生”については，1 本区は根域の $4.9 \%, 2$ 本区は 9.7\%，3 本区は $14.2 \%, 4$ 本区は $18.6 \%$ に相当した. この浸潤域割合と $\psi \max$ との相 関分析を行った結果，両品種ともに灌水開始後 2 週間頃か ら測定中止時まで相関係数 0.8 程度の高い相関関係がみら れた（第 7 図）.

\section{考察}

1. 灌水割合に対する幼木樹および成木樹の乾燥ストレス 間苧谷ら（1976）は，鉢植えの 3 年生 “杉山温州” に抒 いて適湿土㙥中の細根比率が $10 \%$ で葉の $\psi$ max が $-0.8 \mathrm{MPa}$ 程度, $30 \%$ で $-0.7 \mathrm{MPa}$ 程度, $50 \%$ で $-0.6 \mathrm{MPa}$ 程度に保たれることを明らかにしている。本試験のブロッ ク枠で栽培した幼木执よびほ場で栽培した成木に颃いて, 
根域に対する灌水域の割合と $\psi$ max との相関分析を行った 結果, ともに相関係数 0.8 程度の高い相関関係が見られた ことから，根域に対する灌水域の割合を，樹体の乾燥スト レスの目安として利用できると考光られる.

岩崎ら（2012）は, $\psi \max$ が $-1.2 \mathrm{MPa}$ 以下で, ウンシュ ウミカンの旧葉が落ち始めることを報告している. 本試験 の幼木の場合, $-1.2 \mathrm{MPa}$ 以上を維持するには, “不知火’, “興津早生”ともに根域の約 50\%以上の灌水域が必要であ り, 樹冠の拡大を考慮すると, 乾燥ストレスが小さい $75 \%$ 以上が望ましい。これに対して，成木の場合は， $-1.2 \mathrm{MPa}$ 以上を維持するには, ‘不知火’で灌水チューブ 4 本（根域に占める灌水割合 $19.5 \%$ 以上）, “原口早生’ で 3 本以上（根域に占める灌水割合 $14.2 \%$ 以上）が必要であっ た. Taylor・Klepper（1973）は, トウモロコシにおいて, 湿潤土㙉にある $19 \%$ の根が $71 \%$ の吸水を行っていると報 告している。また， Smartら（2005）は，ブドウに拈いて， 灌水域の根から乾燥域の根への水の再配分を確認してい る. これらのことから, カンキッに拈いても, 樹体を維持 するらえで，すべての根に灌水する必要がないと考えられ る. また，幼木は成木に比べて， $-1.2 \mathrm{MPa}$ 以上を維持す るために必要な, 根域に占める灌水割合が高かった。 これ は, 水の貯留器官である幹や枝が細いことから, 乾燥スト レスが付与されやすいためであると考えられる.

ウンシュウミカンは夏秋季に乾燥ストレスを付与するこ とで，果汁内の糖度が上昇し（間艼谷・町田，1980）, $\psi \max$ を $-1.0 \mathrm{MPa}$ 程度に維持することで樹体にダメージ を与えることなく, 増糖効果が期待できる（貝原ら, 2008; 岩崎ら，2012). “不知火’に打いて子夏秋季の乾燥 ストレスによる増糖効果が確認されて扣り, 乾燥ストレス の目安は $\psi \max -0.7 \sim-0.9 \mathrm{MPa}$ 程度とされている(岩崎ら, 2012; 吉田ら，2013). 試験 2-2 では, “原口早生”で灌水 チューブ 3 本区以上（湿潤域 $14.2 \%$ 以上）, ‘不知火’で チューブ 4 本区（湿潤域 $19.5 \%$ 以上）で，期間を通じて $\psi \max -0.9 \mathrm{MPa}$ 以上を維持できた.

\section{2. 点滴灌水チューブの導入方法}

点滴灌水の土䁃中に打ける浸潤傾向については, 土壤母 材による水の拡散程度の差異が調査されており, 土壤の密 度が高いほど浸潤はより横方向に広がるとの報告がある (農林水産省構造改善局, 1994)。本試験においても, 密度 が小さく荒砂の比率が高い花崗岩質土壌は, 垂直方向へ, 荒砂の比率が低い火山灰土壤は，水平方向へ浸潤しやすい 傾向が認められた。 また, 花崗岩質土䁃について, 阿部ら （2014）は，吐出量 $2.3 \mathrm{~L} / \mathrm{h}$ の点滴灌水の浸潤をプロファイ ル土壤水分計を用いて調査し, 垂直方向への浸潤範囲は 7 分間で約 $20 \mathrm{~cm}, 14$ 分間で約 $30 \mathrm{~cm}, 28$ 分間で約 $40 \mathrm{~cm}$ 広 がり，水平方向へは 7 分間で半径約 $4 \mathrm{~cm}, 14$ 分以降は半 径約 $9 \mathrm{~cm}$ までしか広がらないと報告している。これは， 本試験の花崗岩質土䁃における傾向と一致している.よっ て, 吐出量 $2.3 \mathrm{~L} / \mathrm{h}$ のューブを用いる場合, 花崗岩質土
壌に扣いて過剰水が少ない 1 回当たりの灌水時間は 20 分 以内，チューブの点滴孔間隔は $20 \mathrm{~cm}$ 以上がよいと考光ら れた. 他の 3 種類の土壤では, 1 回当たりの灌水時間は 60 分程度までとし，点滴孔間隔は $30 \mathrm{~cm}$ 以上確保することが 望ましいと思われる。

ウンシュウミカンの根群分布については，これまでにも 調査が行われて拈り，10 年生以上のウンシュウミカンで は主幹から約 $2 \mathrm{~m}$ 以内，深さ約 $30 \mathrm{~cm}$ 以内に多くの細根が 存在し, 細根密度は主幹から約 $90 \mathrm{~cm}$ 以内で高いといら報 告が多い（冨士岡ら，1969; 駒村・関谷，1985; 宮本・前田， 2010; 奥地ら，1962; 小野ら，1986)。本試験に打ける“原 口早生’ ‘ ‘不知火’ の根量調査の結果, 吸水器官である 細根は，主幹から $60 \sim 100 \mathrm{~cm}$ を中心に多く，深さ $30 \mathrm{~cm}$ までに 90\%以上分布することが明らかになった。これら のことから, 土壤の物理性, 品種および樹齢などによる差 は考えられるが，カンキッ成木樹の根域を効率的にカバー するための灌水チューブの敷設位置は，主幹から $100 \mathrm{~cm}$ 付近までが適当であると考えられる。 また，大部分の細根 が分布する深さ $30 \mathrm{~cm}$ までの範囲を注沟一に灌水するた めの 1 回当たりの灌水時間は, 試験 2-1 の結果より, 吐出 量 $2.3 \mathrm{~L} / \mathrm{h}$ の灌水チューブを用いる場合, 乾燥条件下の花

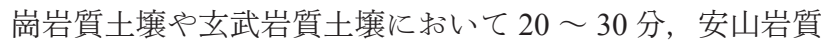
土壤や火山灰土壤に拈いては 60 分程度必要である。これ を満たす灌水を行えば，根域に対する灌水域の割合を平面 的に考えることができる．試験 2-2 の結果から，玄武岩質 土壤に拈いて ‘不知火”は 4 本区（湿潤域は 19.5\%), “原 口早生’ は3 本区（湿潤域は 14.2\%）で樹体の乾燥ストレ スをコントロールできた。すなわち，主幹を中心とした半 径 $2 \mathrm{~m}$ の円の面積（根域面積）のらち, “不知火’で $19.5 \%$ 以上，“原口早生’で $14.2 \%$ 以上の点滴灌水浸潤面 積を確保することで，樹体の乾燥ストレスをコントロール できると推察される.

以上の結果から, カンキッ樹に打ける点滴灌水チューブ の導入に際して，夏秋季の過乾燥を防ぐためのチューブの 設置本数は，玄武岩質土壤の 13 年生 “不知火’で 4 本以 上 (根域に占める灌水割合 $19.5 \%$ 以上), 21 年生 “原口早生” で 3 本以上（根域に占める灌水割合 $14.2 \%$ 以上）を目安と し，細根密度の高い主幹から $100 \mathrm{~cm}$ 以内にチューブを設 置することで根域を効率的にカバーできる。 また，細根域 を無駄なく灌水するための 1 回当たりの灌水時間は, 吐出 量 $2.3 \mathrm{~L} / \mathrm{h}$ のチューブを用いる場合，乾燥条件下の花崗岩 質土壌で 20 分以内, 玄武岩質土壤で $20 \sim 60$ 分, 安山岩 質土壤や火山灰土壤に拈いては 60 分程度が適当であると 考えられる. 灌水間隔日数は, 予備試験の結果, $3 \sim 5$ 日 で湿潤状態を維持できたが，着果量が多い場合は，間隔を 短縮する必要がある（中谷ら，2010）。また，点滴灌水に よる水管理を連年継続した場合, 点滴孔付近に細根が増加 することから（草塲ら，2004），根域に占める灌水割合は 高くなると考光られる。 


\section{摘 要}

樹体の乾燥ストレスをコントロールするために必要な点 滴灌水域を明らかにするため, 灌水域の割合が幼木抢よび 成木の樹体の乾燥ストレスに及洔す影響について調査し た，その結果，根域に対する灌水域の容積割合と樹体の乾 燥ストレスとの間には高い相関関係が認められ，夏秋季の 過乾燥を防ぐためには，幼木の場合，根域の約 $50 \%$ 以上の 灌水域が必要であった。これに対して，成木の場合は，玄 武岩質土壌の 13 年生 ‘不知火’で根域の $19.5 \%$ 以上（本 試験の灌水チューブ 4 本以上)， 21 年生 “原口早生”で根 域の $14.2 \%$ 以上（本試験の灌水チューブ 3 本以上）の灌水 域が目安となることが明らかとなった. チューブは細根密 度の高い主幹から $100 \mathrm{~cm}$ 以内に設置し，1 回当たりの灌水 時間を，乾燥条件下の花崗岩質土壌で 20 分以内，玄武岩 質土䁃で $20 \sim 60$ 分, 安山岩質土壤や火山灰土䁃において は 60 分程度とすることで, 細根域を効率的に灌水できる と考兄られた。 また, 灌水チューブの点滴孔間隔は花崗岩 質土䁃では $20 \mathrm{~cm}$ 以上, 他の 3 種類の土壤では $30 \mathrm{~cm}$ 以上 とすることで無効水を減らすことができると考兄られた。

\section{引用文献}

阿部政人・豊嶋貴司・吉田純也・森末文徳. 2014. 花崗岩 風化土壤のカンキッ園に打ける土壤水分動態に基づく 点滴かん水方法. 香川農試研報. 64:（印刷中）。 土㙥環境分析法編集委員会. 1997. 土䁃環境分析法. p. 24-29. 博友社. 東京.

冨士岡義一・海田能宏・中川泰男. 1969. ミカン園散水カ ンガイの研究（I）一土䁃水分の消費機構について一. 農業土木学会論文集. 27.

岩崎光徳・深町 浩 - 今井 篤 - 平岡潔志 - 奥田 均. 2012. ウンシュウミカンと ‘不知火’に打忷る TDR 計を用いた枝内水分測定法の有用性と水管理方法の検 討. 園学研. 11:327-335.

貝原洋平・宮本輝仁・原口暢朗・池田繁成・新堂高広. 2008. ウンシュウミカン樹に抢ける枝体積含水率の年 間変動と水分環境および水管理. 園学研. 7: 517-523. 駒村研三・関谷宏三. 1985. 土㙵母材，有効土層の差異と ウンシュウミカン樹の生育及び根群分布. 果樹試報 A. 12: 79-92.

草塲新之助・森永邦久 ・星 典宏・島崎昌彦. 2007。 カン キッ等に打忷るマルチ拈よび点滴灌水施肥法の導入の 現状と課題 〜カンキッ生産地に扮ける高品質果実生 産に関する調査報告〜。近中四農研資. 4: 1-20.

草塲新之助・森永邦久 ・島崎昌彦・星 典宏 - 村松 昇
2004. 周年マルチ点滴同時施肥法で栽培されたウン シュウミカンに扔兴細根の割合と呼吸活性. 根の研 究. 13: 111-115.

間苧谷 徹・町田 裕. 1980。夏季に持けるウンシュウミ カン樹の水管理の指標としての葉の水ポテンシャル. 園学雑. 49: 41-48.

間苧谷 徹・町田 裕・山津憲治・山崎隆生. 1976。果樹 の葉内水分不足に関する研究（第 3 報） 土㙥要因が カンキッ葉の water potential に及ぼす影響について。 園学雑. 44: 367-374.

宮本久美・前田隆昭．2010． 有田ミカン産地の表層地質に よる地帯区分と土壤保水性. 和歌山農林水技七研報. 11: 35-43.

森永邦久 ・島崎昌彦・草塲新之助・星 典宏. 2005. カン キッ生産の新しい技術 マルドリ方式一その技術と利 用一. p. 33-36. 近中四農業研究叢書. 広島.

永田 靖. 2003. サンプルサイズの決め方. p. 39-41. 朝 倉書店. 東京.

中谷 章・宮本久美 - 田嶋 皓 - 山田芳裕 - 山本浩之. 2010. 着果負担の違いがウンシュウミカンの細根量に 及洔す影響。園学研．9（別 1）：52.

農林水産省構造改善局. 1994. 土地改良事業計画指針 ? イクロかんがい. p. 60. 農業土木学会. 東京.

奥地 進・薬師寺清司・圓木忠志・船上和喜. 1962. 相橘 の根群に関する研究(第 1 報). 温州ミカンの根群分布. 愛媛果試研報。2: 11-24.

小野祐幸・岩垣 功・高原利雄. 1986. カンキッの根群分 布と葉の着生との関係. 果樹試報 D. 8: 25-36.

Sholander, P. F., E. D. Brandstreet, H. T. Hammel and E. A. Hemmingsen. 1966. Sap concentrations in halophytes and some other plants. Plant Physiol. 41: 529-532.

Smart, D. R., E. Carlisle, M. Boebel and B. A. Nunez. 2005. Transverse hydraulic redistribution by a grapevine. Plant, Cell and Environment 28: 157-166.

高木敏彦・加藤信夫・鈴木鉄男・岡本 茂. 1981. 温州 : カン樹に打ける水ストレスが葉中水ポテンシャル，光 合成及び呼吸に及济す影響. 静岡大学農学部研究報告. 31: 21-25.

Taylor, H. M. and B. Klepper. 1973. Rooting density and water extraction patterns for corn (Zea Mays L.). Agron. J. 65 965-968.

吉田純也・豊嶋貴司・阿部政人・森末文徳．2013．無加温 施設栽培の “不知火”打よび“せとか’ に打ける時期 別乾燥ストレスと果実品質との関係. 近畿中国四国農 研. 23: 35-40. 